\title{
Activated PI3K-Positive Cells Present
}

National Cancer Institute

\section{Source}

National Cancer Institute. Activated PI3K-Positive Cells Present. NCI Thesaurus. Code C153101.

An indication that cells expressing the active form of a phosphatidylinositol 3-kinase (PI3K) family protein has been detected in a sample. 